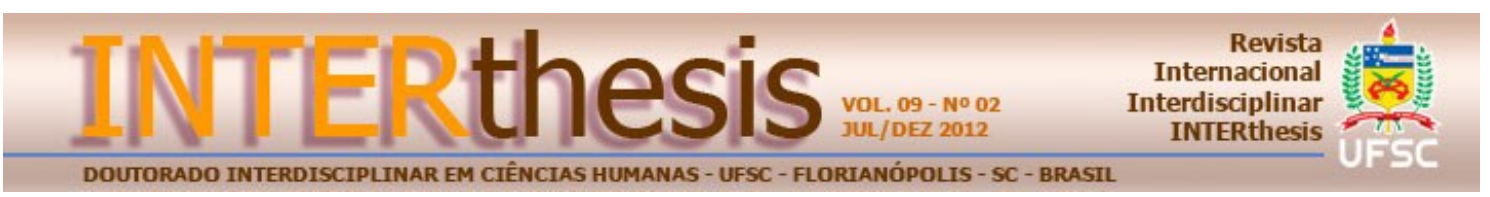

\title{
ANÁLISE DE CONFLITOS SOCIOAMBIENTAIS: O CASO DA COMUNIDADE RURAL DE RIO MAIOR, MUNICÍPIO DE URUSSANGA, SANTA CATARINA
}

\section{ENVIRONMENTAL CONFLICT ANALYSIS: THE CASE OF THE RURAL COMMUNITY OF RIO MAIOR, MUNICIPALITY OF URUSSANGA, SANTA CATARINA STATE}

\section{ANÁLISIS DE CONFLICTOS SOCIO-AMBIENTALES: EL CASO DE LA COMUNIDAD RURAL DE RIO MAIOR, MUNICIPIO DE URUSSANGA, ESTADO DE SANTA CATARINA}

\author{
Daniel Trento do Nascimento ${ }^{1}$ \\ Maria Augusta Almeida Bursztyn ${ }^{2}$
}

\section{Resumo:}

O conflito em análise ocorre na localidade de Rio Maior, município de Urussanga, SC, e aborda a mobilização de uma comunidade contra as atividades de mineração de basalto/diabásio, britagem e usinagem de asfalto conduzidos pela empresa Setep Construções, com sede em Criciúma, SC. O estudo de caso se deu com base na hipótese de que o acirramento dos conflitos socioambientais é um dos fatores determinantes para o fortalecimento das ações e para a formação de estruturas de governança ambiental local e, consequentemente, pela institucionalização da gestão ambiental municipal. Para tanto, após a revisão teórica sobre o tema, foram identificados os principais atores e condicionantes que moldaram a disputa. Por fim, com base na análise do conflito, foi elaborado um mapeamento do mesmo e identificados os principais desdobramentos que corroboram a hipótese da pesquisa.

Palavras-chave: Conflitos socioambientais. Mineração. Gestão Ambiental Local.

\section{Abstract:}

The conflict occurs in the rural community of Rio Maior, municipality of Urussanga, $\mathrm{SC}$, and is related to the community mobilization against mining activities of basalt, diabase and asphalt mill conducted by Setep Construction Company, held in Criciúma, SC. The case was analyzed based on the hypothesis that the increasing of environmental conflicts is one of the determining factors for the strengthening of environmental actions and for the formation of local environmental governance structures and, consequently, for the institutionalization of the municipal

\footnotetext{
${ }^{1}$ Doutor em Desenvolvimento Sustentável pela Universidade de Brasília (UnB). Servidor Público do Ministério do Meio Ambiente, Empresa Brasileira de Pesquisa Agropecuária, Embrapa Agroindustria de Alimentos, Rio de Janeiro, RJ, Brasil. E-mail: danieltrento@hotmail.com

${ }^{2}$ Doutora em Ciências da Água - Gestão Ambiental, Professora do Centro de Desenvolvimento Sustentável da Universidade de Brasília , Brasília, DF, Brasil. E-mail: dute.cds@gmail.com
} 
environmental management. Therefore, after a theoretical review on the subject, it was identified the main players and conditionings that shaped the dispute. Finally, based on the conflict analysis, it was designed a conflict mapping and identified the main outcomes of the conflict that confirms the research hypothesis.

Keywords: Environmental Conflicts. Mining. Local Environmental Management.

\section{Resumen:}

El conflicto analizado ocurre en la comunidad rural de Rio Maior, ubicado en el municipio de Urussanga, SC, y se refiere a la movilización de una comunidad contra las actividades de extracción de basalto y diabasa, trituración y mecanizado de asfalto realizado por la Compañía SETEP, con sede en Criciúma, SC. El análisis de caso tuvo como base la hipótesis de que la intensificación de los conflictos sociales y ambientales es uno de los factores determinantes para el fortalecimiento de las acciones y para la formación de estructuras de gobernanza ambiental local y, en consecuencia, por la institucionalización de la gestión ambiental municipal. Con ese fin, después de la revisión de la literatura sobre el tema, se identificaron los principales actores y las condicionantes que formaron el conflicto. Finalmente, con base en el análisis del conflicto, se ha diseñado un mapeo del mismo y se identificaron las principales repercusiones que apoyan la hipótesis de la investigación.

Palabras clave: Conflictos sociales y ambientales. Minería. Gestión Ambiental Local.

\section{INTRODUÇÃO}

Esta pesquisa foi elaborada com base na hipótese de que o acirramento dos conflitos socioambientais, que é fruto da busca por interesses econômicos, é um dos fatores determinantes para o fortalecimento de ações ambientais, formação de estruturas de governança local e, consequentemente, pela institucionalização da gestão ambiental.

Os conflitos fazem emergir a necessidade de maior regulação ou mediação e assim estruturas de governança vão sendo criadas. Nesse sentido, de forma a analisar a hipótese levantada, foi selecionado um caso de conflito socioambiental envolvendo atividades de mineração em uma comunidade rural instalada numa Área de Proteção Ambiental (APA).

O caso ocorre na localidade de Rio Maior, município de Urussanga, SC, e trata da mobilização da comunidade contra as atividades de exploração de uma pedreira com britagem e mineração de basalto/diabásio ${ }^{3}$, material utilizado para a produção de massa asfáltica.

\footnotetext{
${ }^{3}$ Diabásio [Sin. dolerito]: Rocha hipabissal básica de composição basáltica, fanerítica fina, textura ofítica a subofítica, muitas vezes com porções porfiríticas, frequentemente em diques e sills,
} 
É um caso emblemático, pois a empresa detentora do direito à exploração é a responsável pelo asfaltamento de várias rodovias da região, bem como de estradas vicinais, inclusive na localidade onde é feita a exploração.

Isso coloca, de forma simbólica, o debate entre desenvolvimento e meio ambiente, sendo o desenvolvimento representado pelo asfaltamento e a proteção do meio ambiente representada pela conservação do único manancial de água limpa do município, que abastece a rede de distribuição de água e, também, pelas construções centenárias tombadas pelo Instituto do Patrimônio Histórico e Artístico Nacional (Iphan), que estão sofrendo rachaduras possivelmente causadas por detonações.

É importante registrar que foram visitadas, na mesma região, localidades com atividades minerárias similares, mas sem conflitos entre a comunidade e as indústrias, e com praticamente nenhum processo de fortalecimento da gestão ambiental em curso, diferentemente do que foi encontrado no caso selecionado.

Para a análise dos conflitos, utilizou-se a base analítica desenvolvida por Nascimento (2001), Little (2001) e Theodoro (2005), principalmente. Além disso, o autor avançou na estrutura de análise criando o item "desdobramentos do conflito" de forma a identificar os avanços institucionais no caso em estudo, bem como elaborou um diagrama resumo do conflito com o mapeamento de cenários futuros.

Com base no mapeamento do conflito, buscou-se identificar os elementos de análise e como essas variáveis se comportaram em relação à variável dependente (fortalecimento da gestão ambiental). Foram adotados os seguintes procedimentos: entrevistas não estruturadas com pessoas chave ${ }^{4}$; coleta de materiais informativos, histórico e montagem de um mapa sintético do conflito; elaboração do instrumento de coleta de dados para cada tipo de ator; montagem do caso e análises; discussão com atores; e redação final do caso.

ocorrendo também em porções mais internas de derrames vulcânicos espessos. $O$ termo diabase é usado mais comumente nos EUA, enquanto o sinônimo dolerite é de uso mais comum na Inglaterra. (Fonte: WINGE et. al., 2001)

${ }^{4}$ Cenilda Mazzuco (Acrima); Vani Mazzuco (Acrima); Juceli Cataneo (Acarimo); Luiz Antônio Fabro (Ex-vereador e Secr. de Saúde); Juceli Francisco Júnior (Advogado); Patrícia Mazon (Secr. de Planejamento); Juliana Turazi (Assessora Prefeitura de Urussanga); Alan (Prefeitura de Urussanga); Itamar Dezan (Vereador); Superintendência da Fatma regional Criciúma; Antonio Carlos Stephani (Setep); Cleber Cesconeto (Advogado Prefeitura de Urussanga); Robson Tibúrcio (Advogado Acrima); Abel (Rio Carvão); Luiz Martins (Vereador); Lindomar Cacciatori (Conselho Municipal de Meio Ambiente de Urussanga); Luciano Giordani (Jornal Vanguarda); Giovanna Serafim Couto (MPF); Cap. Theo Silva Santos, Cap. Comeli, Cabo Souza (Polícia Ambiental). 
A pesquisa de campo foi realizada nos meses de junho, julho e dezembro de 2008 e janeiro e julho de 2009, momentos em que foram realizadas entrevistas abertas, não estruturadas, com atores chave no processo envolvendo lideranças comunitárias, a empresa mineradora, políticos, técnicos e funcionários da prefeitura municipal, órgãos ambientais entre outros.

\section{CONFLITOS SOCIOAMBIENTAIS}

\subsection{Análise de conflitos}

Com a maior conscientização da sociedade a respeito dos problemas ambientais, principalmente após a década de 70 (século XX), diversos movimentos começaram a surgir em defesa do meio ambiente aportando mais um elemento nos conflitos sociais antes dominados por relações capital e trabalho, e que a partir daí passam a inserir alguns direitos difusos, como o direito à qualidade de vida, ao meio ambiente sadio e equilibrado, direitos das minorias, direitos humanos entre outros.

Little (2001) define conflitos socioambientais como disputas entre grupos sociais derivadas dos distintos tipos de relação que eles mantém com o seu meio ambiente representando simultâneamente um campo de estudo e também um campo de ação política.

Um conflito ambiental pode ser definido como uma situação manifesta onde há uma valoração contraposta por parte de diferentes atores sociais em relação ao meio ambiente, sendo que os atores envolvidos têm diferentes capacidades e formas de intervir nessa questão ou decisão ambiental (AZKARRAGA, 2008).

Numa visão da economia como um sistema aberto à entrada de energia e materiais e à consequente saída de resíduos, esta saída pode se dar na extração dos materiais e energia, na manufatura, no transporte ou na própria disposição final. Dentro dessa perspectiva, Martinez-Alier (2004) elaborou uma classificação dos conflitos ambientais baseado nos casos mais recorrentes na época (até 2004) da seguinte forma:

Conflitos gerados na extração de materiais ou energia: conflitos mineiros; conflitos pela extração de petróleo; degradação e erosão das terras; florestas plantadas com espécies exóticas; biopirataria; defesa dos mangues; conflitos relacionados à água; direitos nacionais e internacionais de pesca.

R. Inter. Interdisc. INTERthesis, Florianópolis, v.9, n.2, p.157-190, Jul./Dez. 2012 
Conflitos sobre o transporte: relacionados ao transporte de materiais e energia como os derramamentos de óleo no mar causados por petroleiros; conflitos com a construção de oleodutos e gasodutos, hidrovias, portos e aeroportos, bem como linhas de transmissão elétrica.

Conflitos sobre os resíduos e contaminação: contra a utilização de substâncias tóxicas (riscos dos metais pesados); segurança de consumidores e cidadãos (relaciona-se aos riscos incertos como o caso do DDT, pesticidas, transgênicos); exportação de resíduos tóxicos, sólidos e líquidos; contaminação transfronteiriça (chuva ácida, CFC, radiação); direitos iguais aos sumidouros de carbono (relação norte-sul e a "dívida do carbono"

Já Little (2001) classifica os conflitos socioambientais em: (a) conflitos em torno do controle sobre os recursos naturais; (b) conflitos em torno dos impactos ambientais e sociais gerados pela ação humana e natural; (c) conflitos em torno do uso dos conhecimentos ambientais.

Os conflitos relacionados aos recursos naturais, de acordo com Little (2001, p.108), "são conflitos sobre as terras que contém tais recursos e entre grupos que reivindicam essas terras como seu território de moradia ou vivência". Os conflitos sobre a terra apresentam três dimensões principais: (a) dimensão política: decisão sobre os usos e beneficiários; (b) dimensão social: disputa sobre o acesso aos recursos; (c) dimensão jurídica: é a disputa sobre o controle formal dos recursos.

Para Nascimento (2001, p. 95):

\begin{abstract}
Todo conflito reúne um conjunto de atores que se posicionam e se dispõem diferentemente entre si, articulam-se ou se opõem. Movimentam-se constantemente, ocupando ora uns lugares ora outros, pronunciando discursos nem sempre coerentes. Nunca são estáticos, e nem sempre claramente perceptíveis em seus movimentos. É este movimento constante dos atores que torna a análise de conflito simultaneamente intrigante e difícil (NASCIMENTO, 2001, p.95).
\end{abstract}

Dentro dessa ideia, os atores de um conflito podem ser indivíduos, grupos sociais, organizações, coletividade e Estados e, de acordo com Nascimento (2001), podem ocupar os seguintes posicionamentos perante o conflito:

\footnotetext{
${ }^{5}$ As "dívidas de carbono" relacionam-se à ideia de Andrew Simms, que levantou a questão da desproporcionalidade do uso dos sumidouros de carbono, como oceanos, solos e atmosfera, por países do Norte sobre os países do Sul.
} 
a. Promoção: dispostos a se movimentar com todos os seus recursos para que haja um determinado desfecho.

b. Apoio: quando tem uma posição favorável à determinadas inciativas ou desfecho, mas não estão dispostos a se jogar com todas as suas forças no processo.

c. Neutralidade: quando por alguma razão não têm ou não querem assumir posição.

d. Oposição: quando se colocam contra determinadas iniciativas, mas não estão dispostos a utilizar todos seus recursos.

e. Veto: quando utilizam todos os seus recursos possíveis para impedir que o conflito caminhe em um determinado sentido.

Para Little (2001), é mais fácil falar em tratamento dos conflitos socioambientais do que em sua resolução. Dentro dessa ideia, ele apresenta cinco tipos de tratamento de conflitos socioambientais:

a) Confrontação: ocorre como resposta de um dos lados quando o conflito está causando danos muito fortes a um ou mais dos grupos sociais envolvidos;

b) Repressão: são respostas ao conflito iniciado. Existem diferentes formas de reprimir um conflito como ação policial ou imposição estatal por exemplo;

c) Manipulação política: é o tratamento que pode envolver relações clientelistas ou coronelistas, bem como suborno e outras formas de cooptação de certos grupos sociais;

d) Negociação/mediação: busca de meios formais para conciliação dos lados geralmente ocorrendo após algum outro tratamento já adotado;

e) Diálogo/cooperação: este tratamento é o que mais se aproxima com uma solução, pois implica participação voluntária e colaborativa de todas partes envolvidas.

Cada tratamento apresenta seus aspectos positivos e negativos e um mesmo conflito pode passar por vários tipos de tratamento, dependendo da fase que se encontrar.

Os conflitos socioambientais são complexos e como apresenta Theodoro (2005), é importante não se perder a noção de que tais conflitos não são resolvidos por procedimentos binários: bem $\mathrm{x}$ mau, heróis $\mathrm{x}$ vilões, legal $\mathrm{x}$ ilegal, formal $\mathrm{x}$ informal. 
Os conflitos socioambientais não são simples, pois os caminhos para a solução dependem, entre vários fatores, da percepção dos seus protagonistas. As políticas para melhorar a gestão geralmente assumem que os problemas são autoevidentes, mas, na realidade, uma consideração cuidadosa e transparente nas formas que os diferentes atores entendem e percebem os problemas é essencial para se iniciar um diálogo efetivo (ADAMS et al. 2003).

Ostrom (1990), ao analisar fatores determinantes para a evolução institucional, mostra que quando existe diálogo, a probabilidade de surgimento de novas instituições é maior e, por outro lado, a ausência de diálogo é determinante para o não surgimento de novas instituições.

É válido lembrar aqui que diálogo ou negociação é um processo onde as partes determinam o máximo e o mínimo aceitáveis até determinado ponto em que se estabelece o limite dos termos possíveis de acordo (THEODORO, 2005).

O campo do conflito é o espaço de movimento dos atores. Na ciência política, o campo do conflito é conhecido como a arena. Para Nascimento (2001, p.96):

O campo do conflito é também desenhado pelos recursos a que os atores podem recorrer. Nem todos os recursos são passíveis de mobilização em qualquer conflito, nem todos os atores podem recorrer a qualquer recurso, pois os recursos são variados, podendo ser materiais ou simbólicos, silenciosos ou mediáticos, regidos por regras explícitas ou implícitas, por normas morais ou jurídicas (NASCIMENTO, 2001, p.96).

Em relação ao objeto de disputa, este pode ser "material ou simbólico, divisível ou indivisível, laico ou profano, real ou irreal. Os objetos podem variar de natureza, mas são sempre bens ou recursos escassos, ou vistos como tais" (NASCIMENTO, 2001, p. 96).

A respeito do objeto de disputa, Nascimento (2001) ainda ressalta para o fato de que a percepção sobre o objeto é diferenciada entre os atores. Sua leitura, compreensão e valorização são distintas para cada um dos atores.

Sobre essa percepção diferenciada, Adams et al. (2003) colocam que é justamente quando os diferentes atores revelam suas interpretações e percepções sobre o objeto de disputa, é que o debate em torno de novas políticas e decisões se torna mais produtivo. Obviamente que isso não garante um resultado onde todos ganham, mas ao menos pode servir como um início de decisões pactuadas e consensuais. 
Dentro dessa visão, a percepção sobre os problemas de uso dos recursos pode ser formada com base em três tipos de conhecimento: conhecimento do contexto empírico; conhecimento das leis, regras e instituições; e crenças, mitos, valores e ideias (ADAMS et al. 2003).

No que diz respeito aos tratamentos e formas de mediação dos conflitos, Theodoro (2005) coloca que os principais mecanismos que têm sido utilizados no Brasil, além dos meios jurisdicionais públicos muitas vezes limitados, são:

a) Conciliação: meio extrajudicial de tratamento dos conflitos onde as partes já se polarizaram sobre o objeto de disputa e há identificação clara do problema. Sua solução pode resultar em três hipóteses (a desistência de uma das partes, a submissão ou a transação negociada);

b) Arbitragem: meio em que as partes escolhem um árbitro para resolver o conflito pautado por limites estabelecidos por uma cláusula arbitral e ao final as decisões ficam vinculadas a uma sentença arbitral;

c) Mediação: é um meio de tratamento autocompositivo em que o mediador não decide, mas facilita o diálogo. O papel do mediador é explicitar os fatos que the foram narrados pelas partes, seus prós e contras sem tomar partido ou apresentar uma solução definitiva. É um procedimento mais brando e que considera mais os aspectos legais envolvidos no conflito indicado apenas para crises menos intensas.

O caso do conflito na mineração, de acordo com Little (2001), é de sobreposição direta. As comunidades locais requerem o direito sobre suas terras, e os mineradores estão interessados nos recursos naturais do subsolo sem considerar quem tem o controle da superfície, bem como os impactos que surgirão para estes.

$\mathrm{Na}$ maioria das vezes, os grupos que fazem as intervenções alterando o ambiente são os principais beneficiários econômicos de tal atividade e não são estes que arcam com os impactos negativos da exploração dos recursos naturais, ou seja, os grupos que não recebem os benefícios são aqueles que ficam com os impactos gerados e os geradores dos impactos são os que ficam com os benefícios (LITTLE, 2001).

De acordo com Little (2001), em geral, os conflitos socioambientais mais difíceis tendem a acontecer onde há um choque entre diferentes sistemas produtivos. No caso analisado, os agricultores tem sua subsistência baseada numa 
relação direta com o ecossistema onde vivem, diferentemente dos sistemas fabris e industriais.

Mas, como coloca Azkarraga (2008), além da busca por resoluções, a análise de conflitos é relevante para compreender a sociedade. O conflito enfatiza as divergências de perspectivas e interesses e as relações de poder.

Enfim, a teoria de análise dos conflitos apresenta esquemas analíticos que ajudam a compreensão dos atores, seus posicionamentos, a dinâmica e as relações cruciais inerentes ao processo de disputa. Não pretende solucionar os problemas, pois são muitas variáveis que os envolvem, mas busca apresentar elementos chaves e definidores dos mesmos, de forma clara, possibilitando uma melhor tomada de decisão.

Nesta pesquisa, o conflito é visto como um elemento contribuinte para a evolução institucional para a melhor governança local e criação de instrumentos de gestão ambiental municipal. Considera-se que sem os conflitos, essa estrutura institucional levaria mais tempo para surgir, ou mesmo, não existiria.

\subsection{Análise institucional}

Tendo em vista que um dos objetos de análise desta pesquisa é o processo de institucionalização da gestão ambiental municipal, é fundamental se resgatar alguns pressupostos teóricos do estudo da análise institucional.

Para este trabalho, instituições e organizações apresentam conceitos diferentes. Instituição é o conjunto de regras, normas, atores, práticas, condutas etc. Já organização é uma agência de execução dos objetivos para o qual foi criada (ex. Secretaria de Meio Ambiente).

De acordo com Furubotn e Richter (1997), o estudo das instituições teve Ronald Coase como um de seus precursores ao publicar o trabalho sobre a natureza da firma em 1937. Para os autores, instituições são vistas como um conjunto definido de regras, formais ou informais, incluindo-se aí os diversos arranjos que permitem sua aplicação.

Outros dois autores importantes na abordagem desse tema são Douglas North e Elinor Ostrom. O primeiro faz um estudo amplo e detalhado das instituições e seu papel na performance econômica dos países, incluindo um foco para o processo de mudança institucional. Uma de suas análises é centrada na natureza 
das instituições e a consequência disso para a economia. Já Ostrom trabalha a questão da evolução das instituições e a sua importância para a ação coletiva.

Ostrom (1990) analisa o funcionamento das instituições e como elas são alteradas pelos seus indivíduos. Ela procura apontar que, entre o Estado e o mercado, existe um universo de opções. A autora defende que não existe solução única para os problemas de gestão de recursos naturais e que as instituições mudam por diferentes motivos.

Ostrom estuda como podem alguns esforços dar certo em um lugar e fracassarem em outros. De forma geral, ela coloca que um conjunto de regras usadas em um ambiente pode apresentar resultados completamente diferentes se adotadas em outro, devido a uma série de fatores.

De acordo com North (1990), organizações fornecem as estruturas para a interação e ação humana e podem ser de natureza política, econômica, social, educacional, cultural etc. E, para ele, modelar organizações é analisar: estrutura de governança; habilidades; processo de aprendizagem.

Contribuições teóricas recentes têm mostrado o papel de atores individuais e seus interesses na busca por mudanças institucionais. Dessa forma, ao reconhecer que os indivíduos têm poder para a mudança institucional, o estudo das relações de poder entre os atores é fundamental, visto que muitas vezes os atores têm interesses contrários, bem como interpretações diferentes sobre a realidade e capacidades desiguais de influenciar nos resultados (HOWARD-GRENVILLE, 2002)

North (1990, p.05) coloca que a origem das organizações e sua evolução são fortemente determinadas pelo arcabouço institucional. As organizações são criadas para atender a objetivos baseados na estrutura institucional. De acordo com North, enquanto as instituições são as regras do jogo, as organizações possuem as estratégias de como jogar. Assim, as regras são diferentes das estratégias dos jogadores.

As instituições se materializam por meio das organizações. As organizações são formas materiais variadas que expressam as instituições. As instituições não teriam vida e realidade social se não fosse por meio das organizações e, ao mesmo tempo, as organizações não teriam sentido e objetivo se não estivessem informadas pelas instituições (BAREMBLITT, 1996). 


\subsection{Atividades mineiras e conflitos socioambientais no sul catarinense}

O primeiro conflito na região envolvendo mineradora e comunidade foi na localidade de Montanhão, município de Siderópolis, quando a Companhia Siderúrgica Nacional (CSN), em 1988, tentou explorar carvão na área (FREITAS, 1998). Em 1994, na mesma região, a Companhia Carbonífera Belluno resolveu abrir uma mina numa área agrícola, o que acabou resultando na mobilização de aproximadamente 200 agricultores que pressionaram a câmara de vereadores do município, propiciando a transformação da área em uma APA.

No município de Urussanga, em 1995, foi criada a Associação Comunitária do Alto Rio Molha (Acarimo), que apresentava, entre outras demandas, medidas contra o assoreamento dos rios e pela recuperação das áreas degradadas pela mineração do carvão da mineradora Treviso. Na época, de acordo com depoimento de Catâneo (2009), foi feito replantio de árvores e dragagem do rio, melhorando significativamente a qualidade da água.

Outro movimento comunitário contra a mineração se deu no Morro Albino e Morro Estevão, no município de Criciúma, em 1996. Nessas localidades, os moradores conseguiram se articular para a criação de uma Área de Proteção Ambiental (APA).

Em 1999, também no município de Siderópolis, uma comunidade passou a protestar contra perturbações nas moradias e incômodos causados às pessoas e animais devido à lavra iniciada na Mina Trevo, operada pela Indústria Carbonífera Rio Deserto. Essa comunidade, conforme relata Ribeiro e Ferreira (2007), reclamava de fuga das águas superficiais ao rebaixamento do lençol freático com consequente diminuição do nível da água em alguns córregos e poços da zona rural local. Além disso, a comunidade se queixava muito das vibrações sentidas com as detonações.

Com base em negociações, a comunidade conseguiu alguns direitos como a possibilidade de entrar na mina uma vez por mês para monitorar as atividades, bem como foi instalada uma sala no escritório da mina à disposição da comunidade com informações sobre o empreendimento.

De acordo com Ribeiro e Ferreira (2007), o papel exercido pela população local é de grande importância para o monitoramento e fiscalização das atividades da empresa, visto que um programa contínuo de monitoramento dos eventos de 
detonação de uma mina é inviável para os órgãos fiscalizadores devido a falta de pessoal, equipamentos e verbas para isso.

Também na região Sul Catarinense, no município de Içara, conforme Nascimento (2010), ocorre um conflito que já dura quase uma década envolvendo agricultores das comunidades de Santa Cruz e Esperança, contra uma grande empresa de mineração de carvão.

A seguir é apresentado um mapa do Sul de Santa Catarina com destaque para a região carbonífera (Amrec) e com a identificação das localidades onde estão inseridos os conflitos, tanto os primeiros (Montanhão, Rio Molha, Morro Estevão e Morro Albino), quanto os casos mais recentes (Rio Maior e Santa Cruz e Esperança).

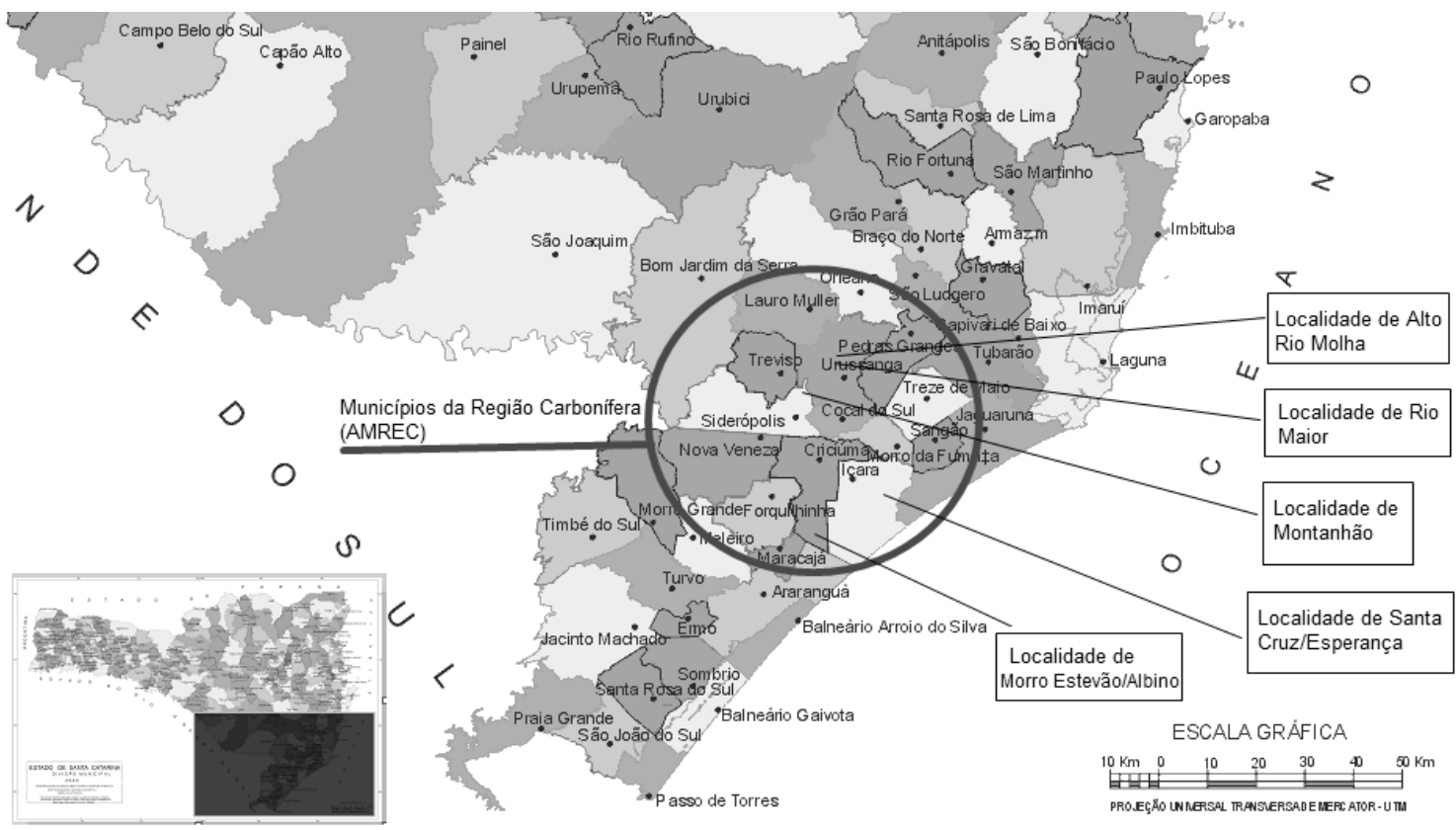

Figura 1: Localização dos casos de conflitos socioambientais e mineração Fonte: NASCIMENTO, 2010.

\section{CONTEXTUALIZAÇÃO DA ÁREA ESTUDADA}

O conflito em questão ocorre na localidade de Rio Maior, no município de Urussanga, sul de Santa Catarina. Rio Maior é uma localidade com atividades de agricultura familiar e turismo rural, que, porém, tem enfrentado problemas com os impactos ambientais das atividades de mineração (basalto/diabásio) e britagem e usinagem de asfalto por parte de uma empresa instalada no local, que também é uma Área de Proteção Ambiental (APA). 
O município de Urussanga localiza-se ao sul do estado de Santa Catarina, nas coordenadas $28^{\circ} 31^{\prime} 04^{\prime \prime}$ de latitude Sul e 49¹9'15" de longitude Oeste e situa-se a uma altitude de 49 metros acima do nível do mar. Fica a $20 \mathrm{~km}$ da cidade de Criciúma e a $185 \mathrm{~km}$ ao sul da capital do estado, Florianópolis. O município integra a Associação dos Municípios da Região Carbonífera (Amrec).

Sua população é formada, em sua maioria, por descendentes de imigrantes italianos e soma aproximadamente 20.000 habitantes (IBGE, 2008). No que diz respeito aos indicadores econômicos, Urussanga possui um PIB de $\mathrm{R} \$ 274.427,00$ (IBGE, 2006), com renda per capita de $\mathrm{R} \$ 14.235,00$ e um IDH de 0,845 (PNUD, 2000).

O município é conhecido como a capital do vinho e há diversas vinícolas em funcionamento na cidade. Quase metade de sua população vive na zona rural e, mesmo assim, o município tem uma economia diversificada com indústrias em diversos seguimentos como de produção de plásticos e cerâmicas, atividade madeireira, fabricação de esquadrias de alumínio, produção de equipamentos agropecuários e o setor mineral (carvão, coque, brita, diabásio, basalto, fluorita e argila). Na agricultura, os principais cultivos são milho, feijão, arroz, fumo e uva (niágara e goethe), bem como a fruticultura, a vitivinicultura e a criação de aves e suínos.

Na sequência, é apresentado um mapa do município de Urussanga (figura 2) com destaque para a APA do Rio Maior com a identificação de áreas de mineração de carvão, bem como das áreas degradadas pela mineração no município. 


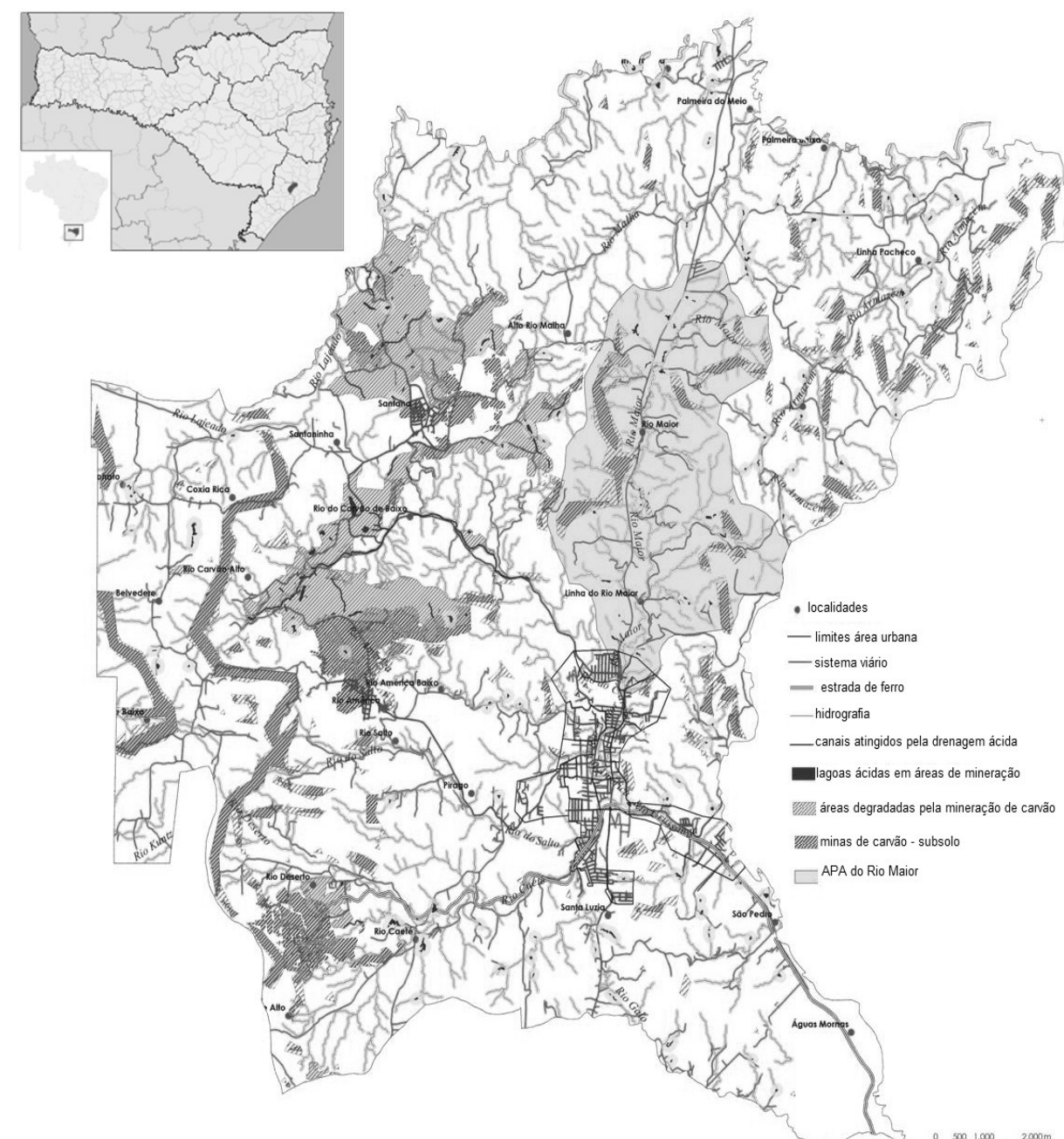

Figura 2: Mapa do Município de Urussanga, SC., com destaque para a APA do Rio Maior. Fonte: PMU, 2008.

A região do conflito faz parte da Bacia do Rio Urussanga, uma das mais poluídas do Brasil pelos dejetos da mineração do carvão. Além da mineração do carvão, que é a maior causadora dos impactos, outras atividades contribuem para a baixa qualidade das águas como a extração de argila, areia, cascalho e fluorita. $O$ rio se caracteriza por elevada acidez com $\mathrm{Ph}<3$ causado pelo enxofre contido no carvão e pela alta concentração de metais pesados como ferro, cobre, manganês, zinco, selênio, magnésio, níquel, cálcio, sódio, entre outros (MENEZES, 2003).

Por outro lado, embora a maioria dos afluentes da Bacia do Rio Urussanga esteja comprometida, o Rio Maior, localizado na área do conflito, ainda possui boa qualidade, sendo o único afluente do Urussanga não poluído pela mineração do carvão (SAMAE, 1995), servindo de manancial para o abastecimento do município, fato este que evidencia ainda mais a importância ambiental da área estudada. 


\subsection{A localidade de rio maior}

O Rio Maior, que dá nome à localidade, é assim chamado por ser o maior afluente do Rio Urussanga. A localidade rural tem uma extensão territorial de 2.406,23 hectares e vivem lá aproximadamente 360 pessoas (120 famílias) compostas por agricultores familiares de descendência europeia, em sua maioria. Os primeiros colonizadores chegaram por volta de 1878, provenientes de Erto-Casso, da província de Pordenone, região Friuli-Venezia-Giulia, Norte da Itália (COMTUR, 2008). A comunidade ainda conserva traços de seus antepassados que podem ser percebidos na arquitetura, na gastronomia e até mesmo na língua, pois muitos ainda preservam o dialeto italiano do norte da Itália de 100 anos atrás.

$\mathrm{Na}$ localidade, além da existência de cinco casarios centenários tombados pelo Instituto do Patrimônio Histórico e Artístico de Santa Catarina (Iphan, SC), sendo dois deles também tombados pelo Patrimônio Histórico Nacional, há ainda diversos atrativos turísticos e naturais como remanescentes de Mata Atlântica ${ }^{6}$, cachoeiras, trilhas, restaurantes, lanchonetes e quiosques com venda de produtos coloniais e vinhos da região, sorveterias típicas italianas e pousadas.

Algumas das atividades econômicas desenvolvidas na localidade são: turismo e gastronomia (setores em processo de crescimento na região); agricultura familiar (embora poucos habitantes ainda vivam exclusivamente da agricultura); avicultura; suinocultura (apenas um produtor); fábrica de móveis planejados; mineração de diabásio/basalto (Setep) e argila (Colorminas), além de indústria de descartáveis plásticos (Thermovac). Existe um grande depósito de explosivos da Explo próximo às instalações da Setep (o que também perturba a população local devido aos riscos de se morar próximo a um estabelecimento desse tipo e porte).

Os principais impactos ambientais identificados na localidade, segundo a Acrima (2009), são: poluição atmosférica e sonora, movimento e rastejo, rachaduras progressivas nas edificações, poluição e assoreamento das águas do rio, bem como acidez nas águas subterrâneas, redução brusca na vazão de água nas fontes naturais e proliferação excessiva de mosquitos borrachudos.

Uma característica recente no município de Urussanga e, especialmente na localidade de Rio Maior, é o fato de que muitos jovens trabalham na Alemanha em

\footnotetext{
${ }^{6} 26 \%$ da área total do município ainda contém fragmentos originais de Mata Atlântica (SOS MATA ATLÂNTICA, 2005).
}

R. Inter. Interdisc. INTERthesis, Florianópolis, v.9, n.2, p.157-190, Jul./Dez. 2012 
sorveterias de proprietários italianos, visto que muitos dos moradores possuem dupla cidadania ítalo-brasileira. Isso faz com que exista um fluxo constante de investimentos movimentando a economia da cidade.

A comunidade de Rio Maior conta com uma bem estruturada associação de moradores, a Associação Comunitária do Rio Maior (Acrima). A Acrima foi fundada em 22 de fevereiro de 1992 e foi declarada de utilidade pública pela lei municipal $n^{\circ}$ 1.413 de 19 de novembro de 1992, e pela lei estadual $n^{\circ} 0056$ de 17 de maio de 1993. A defesa da preservação ambiental consta de seu estatuto desde sua criação.

Um dado importante da área de estudo é que em 1998, com o intuito de se preservar a região do Rio Maior, foi criada por lei municipal ( $n^{\circ} 1665$, de 27 de Novembro de 1998) a Área de Proteção Ambiental (APA) do Rio Maior. Entre os objetivos que embasam a lei, se destacam:

a) Garantir a conservação de expressivos remanescentes de mata aluvial e dos recursos hídricos existentes;

b) Melhorar a qualidade de vida da população residente através da orientação e disciplina das atividades econômicas locais;

c) Fomentar o turismo ecológico, a educação ambiental e a pesquisa científica;

d) Preservar o patrimônio cultural e arquitetônico do meio rural; e

e) Proteger espécies ameaçadas de extinção.

\subsection{A empresa mineradora: Setep Construções Ltda.}

A empresa Setep Construções Ltda. foi criada em 1970, e possui capital social integralizado de $R \$ 20.000 .000,00$ (Vinte milhões de reais) com um patrimônio líquido próximo de $\mathrm{R} \$ 90.000 .000,00$ (Noventa milhões de reais). Sua sede localiza-se no município de Criciúma, SC.

Suas áreas de atuação são construção rodoviária, engenharia civil, engenharia de agrimensura e produção e vendas de massa asfáltica e materiais britados. A área de pavimentação asfáltica foi iniciada na empresa na década de 90 (século XX).

As unidades de produção de massa asfáltica da Setep localizam-se nos municípios catarinenses de Urussanga, Paulo Lopes e Vargem Bonita e sua capacidade de produção total é de 300 toneladas/hora de concreto asfáltico usinado a quente (SETEP, 2008). 
A unidade envolvida no conflito estudado é a de Urussanga, que é composta por um conjunto para processamento de concreto asfáltico usinado a quente, com capacidade para 60/100 t/hora, com os seguintes equipamentos: dosador de agregados; dosador de filler; secador/misturador drum-mixer; queimador; bomba de combustível; exaustor e purificador de ar do tipo filtro de mangas; dosador de asfalto; silo de massa com elevador; unidade de controle eletrônico; ponte de pesagem (balança); aquecedor de asfalto e óleo combustível; tanques de armazenamento (SETEP, 2008).

Além das três unidades de produção de massa asfáltica, a Setep mantém nas mesmas localidades, as unidades de produção de materiais britados com capacidade de produzir até 400 metros cúbicos/hora.

A unidade de extração e britagem de Rio Maior (município de Urussanga) cobre uma área de 39 hectares licenciada junto ao DNPM (Processo $n^{\circ}$ 815.645/96; Alvará $\left.\mathrm{n}^{\circ} 453\right)$, possuindo uma reserva medida de $39.117 .800,00 \mathrm{~m}^{3}$ de rocha basáltica in situ (SETEP, 2008).

Esta unidade está equipada para produção de brita a partir de rocha basáltica para uma produção média de $120 \mathrm{~m}^{3} /$ hora. Utiliza equipamento composto de correias transportadoras para classificação dos materiais britados (SETEP, 2008).

$\mathrm{Na}$ figura 3 segue uma imagem da área da Setep, na unidade de Rio Maior (Urussanga), com destaque para as plantas de britagem e de usinagem de asfalto.

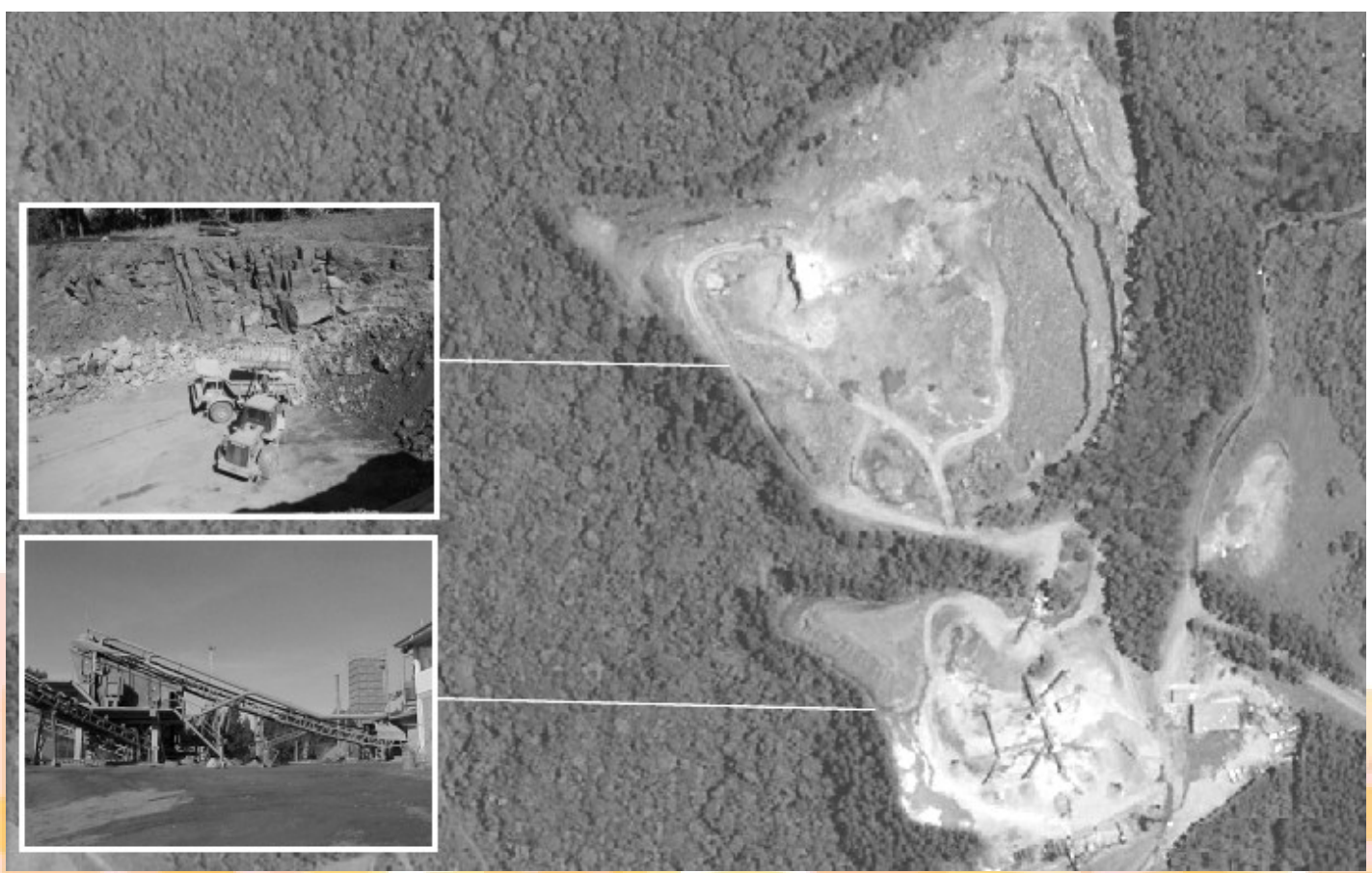

Figura 3: Setep - Unidade de extração, britagem e usina de asfalto em Rio Maior. Fonte: Google Earth, 2009 e Setep, 2008.

R. Inter. Interdisc. INTERthesis, Florianópolis, v.9, n.2, p.157-190, Jul./Dez. 2012 


\section{ANÁLISE DO CONFLITO}

\subsection{Marcos do conflito e objeto de disputa}

O conflito começou a se acirrar a partir de 2002, mas dois eventos importantes e que podem ser considerados os primeiros registros relacionados ao conflito foram, respectivamente:

a) 1987 - início da extração e britagem no Rio Maior: a área foi requerida para pesquisa de basalto junto ao DNPM (Processo $n^{\circ}$ 815.612/87) pela empresa Geotecnia Geologia e Fundações Ltda. De 1987 até 1996, as atividades eram coordenadas pelos residentes locais, Srs. Hugolino e Silvino de Lorenzi Cancelier (Ninão). A Setep só veio adquirir os direitos de exploração e beneficiamento em 1996, quando comprou os direitos da empresa Geotécnica (Ação Civil Pública, 2005), bem como as terras de propriedade do Sr. Silvino;

b) 1989 - criação, por Lei Municipal, da Área de Preservação Ambiental Permanente $^{7}$ (APP) da Microbacia do Rio Maior a fim de proteger o manancial de água que abastece a região das sub-bacias do Rio Maior, Rio Barro Vermelho e seus afluentes. Isso se deu em 05 de dezembro de 1989 (lei municipal $n^{\circ} 1.170$ ). $O$ artigo segundo da lei deixava claro que a "exploração de qualquer atividade produtiva com abrangência na área da presente lei, só será permitida desde que não contrarie as normas federais, estaduais e municipais sobre a matéria". Entretanto, é válido registrar que a lei nunca chegou a ser regulamentada.

Naquela época, a Associação Comunitária do Rio Maior (Acrima) encaminhou uma carta ao órgão ambiental estadual (Fatma) relatando sua preocupação com o futuro da localidade e alertando que a anuência municipal contrariava leis municipais como o capítulo VII da Lei Orgânica Municipal que trata sobre meio ambiente e a lei $\mathrm{n}^{\circ}$ 1.170, que criou a APP do Rio Maior.

Também em 1995, o órgão responsável pela captação e abastecimento de água de Urussanga (Serviço Autônomo de Água e Esgoto - Samae), procurou a Fatma para esclarecimentos, como se observa em trecho da carta:

\footnotetext{
${ }^{7}$ Esta lei é curiosa, pois, mesmo que o Código Florestal já defina o que vem a ser uma Área de Preservação Permanente (APP), o município, por meio da câmara de vereadores, decidiu criar uma Área de Preservação Ambiental Permanente (APP Municipal).
} 
causou-nos estranheza que algumas atividades, altamente agressivas ao meio ambiente, como extrações de minério a céu aberto e a implantação de usina asfáltica vem se instalando na área, algumas, inclusive com licenças expedidas por esse órgão (SAMAE, 1995).

Por sua vez, a Fatma alegou que as atividades minerárias somente foram licenciadas após a declaração de anuência da prefeitura municipal e em relação à usina de asfalto, não havia sido autorizada a sua instalação.

O Samae, em complemento, declarou sua contrariedade à instalação da usina visto que se localizava dentro da área de captação de água da cidade, em área de preservação permanente.

Entretanto, em junho de 1996, a Fatma concedeu a licença de operação à Setep para a atividade de britagem pelo período de 12 meses e, no mesmo mês, a Prefeitura Municipal de Urussanga emitiu a licença $n^{\circ}$ 01/96, para exploração de basalto pelo prazo de 20 anos, numa área de 39 hectares no Rio Maior.

Nesse período, o conflito estava restrito aos envolvidos e a alguns moradores mais ativos da localidade, mas, como poderá ser observado mais adiante, o conflito evoluiu, gerando polêmica em todo o município e região, visto que a mineradora era uma das responsáveis por boa parte das obras de asfaltamento e pavimentação das rodovias do sul Catarinense e a paralisação de suas atividades gerou manifestações regionais.

O objeto de disputa do conflito são os recursos naturais da localidade. Por um lado, está a empresa Setep, que tem interesse econômico na extração de diabásio/basalto e na britagem e usinagem de asfalto. Do outro lado, está a Associação Comunitária do Rio Maior (Acrima) e os moradores que lutam para conservar os recursos naturais, históricos e culturais locais, bem como a qualidade de vida.

\subsection{Natureza e abrangência do conflito}

Este conflito é de natureza social, econômica e ambiental: (a) econômica, visto que envolve as atividades de mineração de basalto/diabásio e britagem e usinagem de asfalto com fins lucrativos por parte da empresa Setep Construções Ltda. Como decorrência do processo industrial, impactos ambientais de diversos tipos são produzidos, o que tem gerado descontentamento na comunidade onde a 
empresa está instalada, ocasionando também o envolvimento de toda a municipalidade, visto que o conflito evoluiu e ampliou suas dimensões. Dessa forma, também é um conflito de natureza (b) social e (c) ambiental, não só pelo fato de o conflito ser dentro de uma APA com um manancial importante para o município, mas também pelos impactos causados nos recursos hídricos, na atmosfera, bem como no patrimônio arquitetônico e cultural da localidade.

A abrangência do conflito é local, pois mobiliza principalmente os moradores da localidade de Rio Maior e do município de Urussanga. Entretanto, ao longo do processo, em diversos momentos, ele se ampliou para dimensões regionais, visto que a paralisação das atividades da empresa ocasionou problemas na pavimentação das ruas dos municípios vizinhos, bem como nas rodovias estaduais SC 446, SC 445 e SC 439. Além disso, muitos funcionários da empresa ou beneficiários diretos das atividades da empresa, como, por exemplo, caminhoneiros que fazem o transporte do material ali explorado, passaram a se posicionar e manifestar com paralisações da rodovia impactando toda região, gerando ampla repercussão na mídia regional.

\subsection{Atores envolvidos no conflito}

Com base nas pesquisas de campo realizadas em junho, julho e dezembro de 2008 e janeiro e julho de 2009, foram identificados os diferentes atores envolvidos no conflito, alguns com participação direta e outros que fizeram ou fazem parte do conflito de forma indireta, a ver:

a) Principais atores que apoiam a Associação Comunitária do Rio Maior (Acrima): Acrima; Cenilda Mazzuco (moradora e atual presidente da Acrima); ex-vereador e político local Luiz Antônio Fabro; Vereadora Vani Mazzuco; grupo de moradores contrários à mineração no bairro; proprietários de empreendimentos turísticos (pousadas e restaurantes).

b) Atores pró-mineradora: Setep Construções Ltda; DNPM; vereador Itamar Dezan; funcionários da Setep; grupo de moradores do bairro favoráveis à Setep; caminhoneiros beneficiados pelos serviços da Setep.

c) Órgãos públicos envolvidos: Fatma; Polícia Ambiental; Samae; Prefeitura Municipal de Urussanga (PMU) e Câmara de Vereadores de Urussanga.

d) Mediadores: TJSC; MPF. 


\subsection{Interesses, posicionamento e identificação das cotas de poder $^{8}$ (formal e informal) de cada grupo}

\subsection{1 - Atores que apoiam a associação comunitária do rio maior (Acrima):}

a) Acrima - Ator principal com poder formal de representar os moradores do bairro.

i. Intenções: mostrar que a empresa não cumpre a legislação e opera de forma lesiva ao meio ambiente comprometendo a qualidade de vida da localidade.

ii. Posicionamento: promoção do conflito.

iii. Ações: responsável pela Ação Civil Pública; Contratação de Advogado; Promoção e organização de reuniões e articulações com a sociedade local.

b) Cenilda Mazzuco - Liderança forte no bairro e presidente da Acrima.

i. Intenções: executar suas atividades de presidente da Acrima e paralisar as atividades da empresa.

ii. Posicionamento: apoio.

iii. Ações: foi uma das pessoas-chave dentro da Acrima para que a mesma se manifestasse contra os impactos gerados pelas atividades da Setep culminando com a Ação Civil Pública.

c) Luiz Antônio Fabro - Político local e ex-vereador do município com forte influência no bairro. Foi um dos fundadores da Acrima.

i. Intenções: acompanhar o processo e apoiar a localidade e a Acrima.

ii. Posicionamento: apoio.

iii. Ações: foi o vereador responsável pelo Projeto de Lei de Criação da APA do Rio Maior. Até 2002 tinha um papel importante nas articulações da Acrima. Ao longo do processo, por questões políticas, foi diminuída sua participação.

d) Vani Mazzuco - Vereadora do bairro com forte influência na comunidade local. Foi a vereadora mais votada no município.

i. Intenções: acompanhar o processo e apoiar a localidade e a Acrima.

ii. Posicionamento: apoio.

iii. Ações: apoio à comunidade nas votações (vereadores) e defesa da causa da Acrima perante a sociedade.

\footnotetext{
${ }^{8}$ Em seu significado mais geral, poder significa a capacidade ou a possibilidade de agir, de produzir efeitos, de influenciar, indivíduos e grupos humanos (adaptado de BOBBIO, 2004, p.933).
} 
e) Grupo de Moradores contrários à mineração no bairro:

i. Intenções: lutar contra os danos e impactos causados pelas atividades da empresa.

ii. Posicionamento: apoio e promoção do conflito.

iii. Ações: participação das reuniões, audiências públicas e assinatura de abaixoassinados.

f) Proprietários de empreendimentos turísticos (pousadas e restaurantes):

i. Intenções: desenvolver atividades ligadas ao turismo rural.

ii. Posicionamento: apoio.

iii. Ações: apoio à causa da Acrima.

\subsection{2 - Atores Pró-mineradora:}

a) Setep Construções Ltda. - Empresa envolvida no conflito. Moderada influência política regional e forte influência local:

i. Intenções: interessado direto na manutenção das atividades industriais.

ii. Posicionamento: veto.

iii. Ações: todos os procedimentos com o objetivo de manutenção das atividades desde procedimentos legais e formais até tentativa de convencimento da sociedade local da importância da empresa para o desenvolvimento da região.

b) Vereador Itamar Dezan - Poder de influência formal e local devido ao cargo ao qual ocupa e moderada influência informal na comunidade junto ao grupo favorável à empresa:

i. Intenções: defender manutenção das atividades da empresa no bairro.

ii. Posicionamento: oposição ao conflito.

iii. Ações: defesa da importância da empresa para o bairro nas suas instâncias de atuação e junto à comunidade local.

c) Funcionários da Setep:

i. Intenções: apoiar a manutenção da empresa no local de forma a garantir seus empregos.

ii. Posicionamento: veto. 
iii. Ações: participação nas reuniões e audiência pública. Campanha contra a chapa vencedora da Acrima e tentativa de influenciar moradores da importância da Setep para o bairro e o município.

d) Caminhoneiros beneficiados pelos serviços da Setep:

i. Intenções: apoiar a manutenção da empresa no local de forma a garantir seus empregos.

ii. Posicionamento: oposição ao conflito.

iii. Ações: participação nas reuniões e audiência pública. Paralisação da rodovia em forma de protesto contra o fechamento da mineradora.

e) Grupo de moradores do bairro favoráveis à Setep - pessoas ligadas de alguma forma à empresa com interesses na manutenção das atividades:

i. Intenções: apoiar a manutenção da empresa no local.

ii. Posicionamento: oposição ao conflito.

iii. Ações: participação nas reuniões e audiência pública. Lançamento de uma chapa alternativa para a eleição da Acrima e tentativa de influenciar moradores da importância da Setep para o bairro e o município.

\subsection{3 - Posicionamento dos órgãos públicos envolvidos no conflito:}

a) Fatma: Poder formal relevante, pois é o órgão estadual responsável pela gestão ambiental e emissão de licenças ambientais. Entretanto, ao longo do processo em análise, concedeu diversas licenças irregulares e tem um posicionamento muito mais favorável à empresa mineradora do que à comunidade.

b) Polícia Ambiental: Poder formal relevante. Tem a atribuição de fiscalizar atividades ilegais que causam danos ao meio ambiente como, por exemplo, mineração, poluição e agrotóxicos. Atua em todo o território catarinense e na área do conflito, o pelotão responsável está localizado no município de Maracajá, SC.

c) DNPM: Poder formal, por ser uma instituição federal dedicada à pesquisa e produção mineral e tem o interesse no desenvolvimento da atividade minerária. Apoiou em boa parte do conflito os argumentos da empresa favorável a manutenção das atividades.

d) Samae: Serviço Autônomo Municipal de Água e Esgoto. Esteve envolvido no 
conflito em diversas fases, principalmente pelo fato de o Rio Maior ser um manancial de água importante para o município. Sempre se mostrou preocupado com os impactos gerados pelas atividades da Setep e em diversos momentos se posicionou formalmente contra as atividades da empresa.

e) Prefeitura Municipal de Urussanga: Poder formal relevante. Responsável pela emissão de anuência, alvarás e declarações de regularidade legal das atividades da empresa de forma a subsidiar a tomada de decisão da Fatma e DNPM para emitir ou não o licenciamento das atividades. Também coordenou a implantação do Plano Diretor Participativo no município.

f) Câmara de Vereadores de Urussanga: Poder formal relevante. Responsável pela aprovação das leis de criação da APP do Rio Maior, da APA do Rio Maior, bem como por referendar e aprovar os documentos referentes ao Plano Diretor do Município.

\subsection{4 - Posicionamento dos Mediadores:}

a) MPF: Poder formal importante e decisivo em vários momentos do conflito e entrou com a Ação Civil Pública contra a mineradora em conjunto com a Acrima.

b) TJSC: Poder formal nas decisões em que foi acionado, e é nesta instância que corre o processo de Ação Civil Pública impetrado pelo MPF e Acrima contra a Mineradora, Prefeitura de Urussanga, DNPM e Fatma. O Tribunal Regional Federal da $4^{\text {a }}$ Região, em Porto Alegre, RS., foi acionado em diversos momentos.

\subsection{Mapeamento do conflito e cenários futuros}

Na sequência, de forma a apresentar uma síntese da dinâmica do conflito, foi elaborado um mapeamento geral do mesmo e as interações mais marcantes ao longo do processo. Como o conflito ainda não se encerrou, também se procurou fazer um exercício para traçar os possíveis cenários, como se observa na figura 4 : 


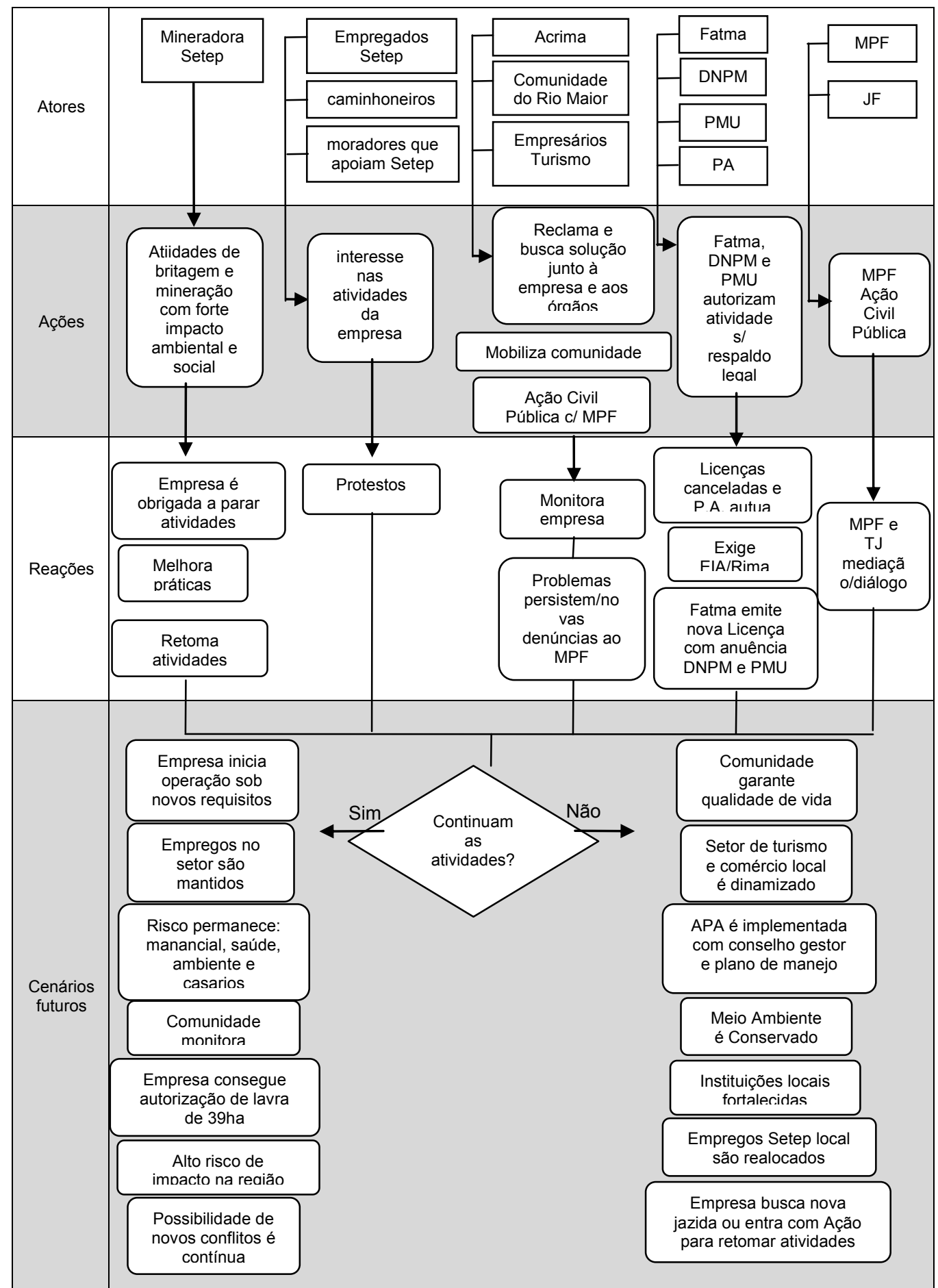

Figura 4: Mapeamento do conflito do Rio Maior e cenários futuros.

Fonte: Elaboração própria, 2009.

Abaixo, com base na matriz de análise de conflito de Theodoro (2005), o resumo do conflito analisado é apresentado no quadro 1. 


\begin{tabular}{|l|l|}
\hline $\begin{array}{l}\text { Natureza } \\
\text { conflito }\end{array}$ & Econômica, social e ambiental. \\
\hline Objeto de disputa & $\begin{array}{l}\text { Recursos naturais. Minério por parte da empresa; água e serviços } \\
\text { ambientais por parte da comunidade, bem como a preservação do } \\
\text { patrimônio histórico e cultural e manutenção da qualidade de vida. }\end{array}$ \\
\hline Campo do conflito & Local e regional. \\
\hline Atores principais & $\begin{array}{l}\text { Empresa Mineradora; associação de Moradores; vereadores; } \\
\text { comunidade local; prefeitura Municipal; fatma; MPF; DNPM; Polícia } \\
\text { Ambiental; Samae. }\end{array}$ \\
\hline Dinâmica & $\begin{array}{l}\text { a) Empresa explora diabásio/basalto, e promove a britagem e usinagem } \\
\text { de asfalto; b )comunidade se queixa da poluição atmosférica, hídrica e } \\
\text { sonora e entra com uma ação civil pública; c) MPF e outros órgãos } \\
\text { entram na mediação, mas o consenso é difícil; d) a empresa adota } \\
\text { alguns procedimentos para se adequar às novas exigências, mas a } \\
\text { comunidade continua a se queixar das atividades impactantes. A } \\
\text { Justiça deu ganho de causa à comunidade e condenou a empresa e } \\
\text { demais órgãos, mas mesmo assim a Fatma concedeu licença e a } \\
\text { empresa continua suas atividades. A comunidade ainda luta por seus } \\
\text { direitos junto ao MPF e Justiça Federal. }\end{array}$ \\
\hline
\end{tabular}

Quadro 1: Matriz síntese do conflito em Rio Maior.

Fonte: NASCIMENTO, 2010.

\subsection{Desdobramentos do conflito}

Neste tópico, busca-se identificar os desdobramentos do conflito mais importantes e significativos. Tendo em vista o conceito de instituição adotado neste estudo (OSTROM, 1990; NORTH, 1990; BAREMBLITT, 1996), no sentido que instituições são leis, regulamentos, condutas, práticas costumeiras e reconhecimento social das estruturas que garantem a efetividade das condutas, abaixo são apresentados os desdobramentos do conflito que ajudam a corroborar a hipótese levantada, qual seja, de que os conflitos socioambientais contribuem para o fortalecimento de ações ambientais e para a evolução institucional.

No caso em questão, percebe-se que houve pouco fortalecimento das ações do órgão estadual de meio ambiente (Fatma), mas certamente houve um aumento das estruturas de governança local com atuação do MPF e Polícia Ambiental, bem como forte participação da comunidade na vigilância e denúncia de atividades danosas ao meio ambiente no bairro.

Abaixo seguem alguns aspectos importantes que merecem ser destacados como avanços no processo:

\subsection{1 - Práticas e processos revistos pela empresa:}

- Após pressão da comunidade, a empresa teve de fazer algumas concessões. Mudanças em diversas práticas que, mesmo que a empresa consiga o direito 
de continuar suas atividades, isso já será efetivado sob outros padrões de funcionamento, visto que, ao longo do processo, ela teve de adotar algumas condutas não planejadas antes do conflito, como:

- Pavimentação do trecho que a liga à SC 446, para evitar a poeira;

- Instalação de um filtro para limpar a poeira que, segundo a comunidade, não era eficaz;

- Instalação de um sistema de aspersão no pátio;

- Plantio de árvores ao redor do terreno para diminuir a poluição visual;

- Construção de tanques de decantação para evitar que, em caso de vazamento, os resíduos poluem a água da localidade.

- A empresa foi impedida de queimar xisto, passando a utilizar gás liquefeito.

- O estabelecimento de um programa de monitoramento no entorno da unidade da Setep, em Rio Maior, como decorrência da solicitação da comunidade, em junho de 2003. Embora tenha sido uma ação pontual com vistas a levantar informações para identificar os potenciais impactos gerados pelas atividades da empresa, cujos resultados não identificaram muita coisa, há que se reconhecer que isso já foi uma ação resultante da postura da comunidade.

\subsection{2 - Leis, normas, acordos e regulamentos:}

- A ação civil pública movida pelo Ministério Público Federal em conjunto com a comunidade para buscar uma solução para os problemas de poluição sonora e atmosférica, rachaduras e redução de água nas fontes naturais foi um grande avanço, pois serviu de exemplo para comunidades vizinhas.

- Assinatura conjunta do Termo de Compromisso de Ajuste de Conduta em que a empresa Setep aceitou contratar equipe para a realização de estudo acerca dos possíveis problemas decorrentes das atividades da empresa, de forma a dirimir as divergências entre comunidade e empreendedor.

- Tendo em vista o acirramento do conflito, uma das alternativas propostas pela Justiça Federal ao longo do processo foi um acordo para a retomada das atividades da empresa no prazo de 210 dias, de forma a permitir a realização

R. Inter. Interdisc. INTERthesis, Florianópolis, v.9, n.2, p.157-190, Jul./Dez. 2012 
de perícia, bem como para dar continuidade e finalizar as obras na região. Os termos do acordo restringindo as atividades e ditando algumas regras pode ser considerado um avanço.

\subsection{3 - Melhoria nas práticas dos órgãos públicos envolvidos:}

- Também se verificou, de acordo com Alano e Mazzon (2009), que a prefeitura municipal de Urussanga aprendeu muito com o conflito do Rio Maior. Ao mesmo tempo que a prefeitura enfrentou dificuldades, o caso em questão foi um fator importante para que o município iniciasse o processo de criação de seu órgão municipal de meio ambiente, assim como o conflito exigiu maior ação por parte do Conselho Municipal de Meio Ambiente.

- O órgão ambiental do Estado (Fatma) emitiu um relatório técnico apontando irregularidades nas atividades de britagem, usinagem de asfalto e extração de basalto e lavrou auto de infração. Muito embora, isso seja atribuição do órgão, essa não é uma prática muito comum na região e considera-se que esse fato foi motivado pelo questionamento de todos os órgãos que receberam a carta denúncia da associação de moradores.

- Plano de monitoramento sísmico de desmonte de rocha com explosivos exigido pelo DNPM. Mesmo que esta seja uma prática e um plano requerido pelo órgão em outros empreendimentos, o mesmo só foi feito na unidade da Setep após pressão da comunidade.

- Implantação de saneamento básico a partir de 1996, em parceria com a Associação Comunitária do Rio Maior (Acrima). Embora essa ação não seja decorrência direta do conflito, há de se reconhecer que a comunidade ganhou respaldo com sua atuação no caso Setep.

\subsection{4 - Conquistas sociais, aprendizado e ações de educação ambiental:}

- A associação de moradores iniciou uma série de reuniões com empresas responsáveis pela extração de argila, basalto, britagem e usina de asfalto no bairro, bem como passou a se reunir com representantes da prefeitura, câmara de vereadores e órgãos ambientais. 
- Promoção de cursos na área de turismo rural, gastronomia e empreendedorismo mostrando uma busca por alternativas de desenvolvimento e não apenas a crítica a empreendimentos poluidores na atualidade.

- A empresa de água e esgoto da cidade (Samae) lançou o projeto "Preservar Urussanga" e escolheu a localidade de Rio Maior para promover o seu lançamento. Isso além de ressaltar a importância ambiental da área, reforça o trabalho de conscientização sobre a importância da questão ambiental.

- Implantação do Projeto "Preservar Vida Bem Maior".

- Palestra sobre meio ambiente promovida pela associação de moradores com a participação de autoridades locais para discutir os problemas ambientais da localidade.

\section{CONSIDERAÇÕES FINAIS}

Este estudo mostra a luta de uma comunidade contra os impactos ambientais ocasionados pela mineração de diabásio/basalto, bem como pela atividade de britagem e usinagem de asfalto.

Sabe-se da importância dos recursos minerais para o desenvolvimento. No caso analisado, um dos lados do desenvolvimento era simbolizado pelo asfaltamento e pavimentação das ruas e rodovias da região. O outro lado, mesmo que pouco relacionado ao desenvolvimento pelas autoridades locais, era o direito da comunidade lutar pela manutenção da qualidade de vida.

O problema central é que a atividade executada pela empresa estava impactando sobremaneira não só o ambiente, mas também a saúde das pessoas e as construções, algumas delas centenárias, o que, de certa forma, estava colocando o acervo histórico e cultural também em risco.

Já se vão oito anos desde que a comunidade passou a se organizar e lutar por seus direitos. Como pôde ser observado nos desdobramentos do conflito, houve avanços consideráveis e, mesmo que a empresa continue com suas atividades, isso ocorrerá dentro de outros padrões de produção, bem como de fiscalização, tanto por parte da comunidade, como dos órgãos responsáveis.

Por outro lado, pode ser percebido o quanto práticas e condutas prejudiciais ao meio ambiente estão arraigadas na cultura dos empreendedores e políticos da 
região, ou seja, ainda sobrevive a velha mentalidade da época de exploração desenfreada do carvão, não importando o impacto ambiental e social. Isso se verificou com a insistência da empresa em não admitir que boa parte dos impactos ambientais causados na APA eram decorrentes de suas atividades. O mesmo também pode ser observado na postura do órgão estadual de meio ambiente (Fatma) que ora mostrava um posicionamento mais técnico (quando pressionada pelo MPF ou outros órgãos), ora se mostrava submissa aos interesses políticos e econômicos da região.

Nesse processo de luta por seus direitos, algumas lições foram deixadas pela comunidade do Rio Maior como a postura ativa da associação de moradores (Acrima), pois foi ela que deu início ao processo e acompanhou todos os trâmites.

Outro fator importante para o sucesso das investidas da Acrima foi o fato da Ação Civil Pública ter sido proposta na forma de litisconsórcio ${ }^{9}$, fazendo com que a Acrima e o Ministério Público fossem parceiros na ação, pois isso deu força e respaldo para a comunidade, uma vez que todo acordo e decisão referente ao processo precisava ouvir tanto o MPF como a Acrima.

Pelo lado da empresa, de acordo com Stephani (2009), a Setep teve muito prejuízo em todo conflito. Além da interrupção das atividades, teve de gastar muito dinheiro com advogado, perícia, EIA/Rima, o que ocasionou uma redução da lucratividade para $1 / 3$, em comparação com a unidade da Setep localizada em Paulo Lopes, SC.

Entretanto, se a empresa tivesse adotado uma postura mais conciliadora desde o início, esse prejuízo poderia ter sido minimizado. A empresa persistia na alegação de que os impactos a ela atribuídos não haviam sido comprovados e que o principal motivo do conflito era a concorrência de setores econômicos disputando uma mesma área, ou seja, o turismo versus a mineração (STEPHANI, 2009).

Ao longo do conflito, pode-se perceber que esse argumento não teve respaldo e que as licenças que embasavam legalmente o direito de explorar as atividades tinham sido emitidas de forma irregular, sem respaldo técnico e sem o importante EIA/Rima. Prova disso foi a sentença da Justiça Federal mandando paralisar todas as atividades e condenando a empresa à reparação dos danos causados, assim

\footnotetext{
${ }^{9}$ Litisconsórcio é um dispositivo do Direito Processual Civil Brasileiro que representa a pluralidade de partes nos processos judiciários. Já, litisconsórcio ativo se dá quando ocorre pluralidade de autores da ação.
}

R. Inter. Interdisc. INTERthesis, Florianópolis, v.9, n.2, p.157-190, Jul./Dez. 2012 
como a declaração de nulidade das licenças ambientais expedidas pela Fatma e pelo município.

Pelo lado da comunidade, embora se reconheça os avanços, algum custo havia que ser assumido por ela no processo e, após o acirramento das relações entre a Acrima e a Setep, que possuía vários funcionários moradores da localidade, bem como moradores com algum tipo de interesse na manutenção das atividades da mineradora, houve uma certa divisão da comunidade, que tinha um histórico de unidade ao longo dos anos.

Outra questão a se ressaltar é que ambos os lados tiveram de ceder no conflito e isso pode ser percebido durante a conciliação intermediada pela Justiça Federal. Um desses momentos ocorreu quando a empresa teve de aceitar a perícia feita por um especialista nomeado pela comunidade, enquanto que esta teve de aceitar a retomada das atividades da empresa para que fosse possível se efetuar os estudos.

Também se verificou que a câmara de vereadores tem forte peso nas decisões municipais, visto que todo instrumento legal deve passar por seu crivo. Isso pôde ser percebido neste estudo quando o meio ambiente foi considerado na aprovação das leis da APP (lei $n^{\circ} 1.170 / 89$ ) e da APA (lei $n^{\circ} 1.665 / 98$ ), e foi ignorado quando a Câmara rejeitou a recomendação do MPF para alterar a redação aprovada no Plano Diretor que permitia a mineração na localidade.

Outro fato relevante verificado no conflito foi a importância que assumem as prefeituras municipais na emissão de licenças ambientais, sejam elas de competência do Estado ou da União, pois, nos dois casos, o município necessita emitir uma declaração de anuência ou alvará. Assim, percebe-se a importância do município no licenciamento ambiental, mesmo quando este não tem competência para tal.

A responsabilidade ambiental dos municípios geralmente é ignorada. $\mathrm{O}$ que este caso nos mostra é que quando se fala em descentralização da gestão ambiental é preciso ir além, pois não basta descentralizar, tem-se que se criar estruturas de governança, programas de educação ambiental, não só para a sociedade, mas para os prefeitos, vereadores e empresários locais. 


\section{REFERÊNCIAS}

ACRIMA. Associação Comunitária do Rio Maior. Apresentação ppt. Disponível em: <http://www.aguas.sc.gov.br/sirhsc/biblioteca_visualizar_arquivos.jsp?idEmpresa=41 \&idPasta=357> Acesso em: 23 Abr. 2009.

ADAMS, W. M. et al. Managing Tragedies: Understanding Conflict over Common Pool Resources. Science, n. 302, p. 1915-1916, 2003.

ALANO, E.; MAZZON, P. Prefeitura Municipal de Urussanga. Urussanga, SC: 06 Jan. 2009. Entrevista concedida a Daniel Trento do Nascimento.

AZKARRAGA, L. U. Movimentos anti-mineros: el caso de Pascua-Lama en Chile. Revista Iberoamericana de Economia Ecológica, Morélia, v. 8, p. 63-77, 2008.

BAREMBLITT, G. Compêndio de análise institucional e outras correntes - teoria e prática. Rio de Janeiro: Rosa dos Tempos, 1996.

BOBBIO, N. Dicionário de política. Brasilia: UnB, 2004.

CATÂNEO, J. Acarimo. Urussanga, SC: 26 Jul. 2009. Entrevista concedida a Daniel Trento do Nascimento.

COMTUR. Conselho Municipal de Turismo da Prefeitura Municipal de Urussanga. Informativo do Vale do Rio Maior. 2008.

FREITAS, E.B. O movimento popular de Rio Albina (Siderópolis).1998. Monografia. Curso de Especialização em Educação Ambiental. Escola Agrotécnica Federal de Sombrio, SC, Santa Rosa do Sul, 1998.

FURUBOTN, E.G; RICHTER, R. Institutions and economic theory: the contribution of the new institutional economics. Ann Arbour: University of Michigan Press, 1997.

HOWARD-GRENVILLE, J. A. Institutional evolution: the case of the semiconductor industry voluntary PFC emissions reduction agreements. In: HOFFMAN, A.; VENTRESCA, M. J. Organizations, Policy and the Natural Environment: institutional and strategic perspectives. California: Stanford University Press, 2002. 
IBGE. Instituto Brasileiro de Geografia e Estatística, 2006. Disponivel em: <http://www.ibge.gov.br/home/estatistica/economia/pibmunicipios/2006/tab01.pdf>. Acesso em: 26 Jun. 2008.

IBGE. Instituto Brasileiro de Geografia e Estatística, 2008. Disponivel em: <http://www.ibge.gov.br/home/estatistica/populacao/estimativa2008/POP2008_DOU. pdf>. Acesso em: 15 Jan. 2009.

LITTLE, P. Os conflitos socioambientais: um campo de estudo e de ação política. In: BURSZTYN, M. A difícil sustentabilidade: política energética e conflitos ambientais. Rio de Janeiro: Garamond, 2001.

MARTINEZ-ALIER, J. Los conflictos ecologico-distributivos y los indicadores de sustentabilidad. Revista Iberoamericana de Economia Ecológica, v. 1, p. 21-30, 2004.

MENEZES, C.B. Tratamento de efluentes ácidos de mina por neutralização e remoção de metais. 2003. 123f. (Doutorado em Eng. Mineral). Escola Politécnica da Universidade de São Paulo/USP. São Paulo: USP, 2003.

NASCIMENTO, D.T. O papel dos conflitos socioambientais e de eventos climáticos extremos na institucionalização da Gestão Ambiental Municipal. 2010. 325f. (Doutorado em Desenvolvimento Sustentável). Universidade de Brasília - UnB. Brasília, 2010.

NASCIMENTO, E. P. Os conflitos na sociedade moderna: uma introdução conceitual. In: BURSZTYN, M. A difícil sustentabilidade: política energética e conflitos ambientais. Rio de Janeiro: Garamond, 2001.

NASCIMENTO, D.T.; BURSZTYN, M.A.A. Análise de conflitos socioambientais: atividades minerárias em comunidades rurais e Áreas de Proteção Ambiental (APA). Desenvolvimento e Meio Ambiente, Curitiba, v. 22, p. 65-82, jul./dez, 2010.

NORTH, D. Institutions, Institutional Change and Economic Performance. Cambridge, Cambridge University Press. 1990.

OSTROM, E. Governing the Commons: the Evolution of Institutions for Collective Action. Cambridge: Cambridge University Press, 1990. 
PREFEITURA MUNICIPAL DE URUSSANGA. Plano Diretor. 2008. Disponível em: $<$ http://www.urussanga.sc.gov.br/conteudo/?item=24648\&fa=10554> Acesso em 15 Nov. 2008.

PROGRAMA DAS NAÇÕES UNIDAS PARA O DESENVOLVIMENTO. Atlas do Desenvolvimento Humano. PNUD, 2000. Disponível em: <www.pnud.org.br>. Acesso em: 12 Out. 2008.

RIBEIRO, J. T. M.; FERREIRA, G. C. Mineração subterrânea de carvão x comunidade no seu entorno: um exemplo de Santa Catarina. REM, Ouro Preto, v.60, n.3, 459 - 464. jul./ set. 2007.

SERVIÇO AUTÔNOMO DE ÁGUA E ESGOTO. [Carta ofício] Urussanga, 07 dez. 1995 [para] Fatma. 1995.

SETEP CONSTRUÇÕES Ltda. Material institucional Construindo o Desenvolvimento. 2008.

SOS MATA ATLÂNTICA. Atlas dos remanescentes florestais da Mata Atlântica, 2005. Disponivel em: <http://mapas.sosma.org.br/>. Acesso em: 09 Mai. 2009.

STEPHANI, A. C. SETEP. Criciuma, SC: 06 Jan. 2009. Entrevista concedida a Daniel Trento do Nascimento.

THEODORO, S. H. Mediação de conflitos socioambientais. Rio de Janeiro: Garamond, 2005.

WINGE, M. E. A. Glossário Geológico llustrado. Brasília, DF, 2001. Disponível em: <http://www.unb.br/ig/glossario/>. Acesso em: 07 maio 2009.

Artigo:

Recebido em: Agosto/2011

Aceito em: Agosto/2012 